\title{
A CASE STUDY: ASSESSING THE CURRENT SITUATION OF FOREST PRODUCTS INDUSTRY IN TAŞKÖPRÜ THROUGH SWOT ANALYSIS AND ANALYTIC HIERARCHY PROCESS
}

\author{
*Bahadır Çağrı BAYRAM1, Tutku ÜÇÜNCÜ ${ }^{1}$ \\ ${ }^{1}$ Kastamonu University, Faculty of Forestry, Forest Industry Engineering Department, \\ Kastamonu/TURKEY \\ *Corresponding author: bcbayram@kastamonu.edu.tr
}

Received date: 08.22.2016

\begin{abstract}
The aim of the study is representing the situation of Taşköprü's forest products industry and specifying its optimum competitive strategy to make it more effective in the region. The condition of the industry in Taşköprü was tried to be identified with a hybrid method which is composed of SWOT analysis and analytic hierarchy process (AHP).

The SWOT analysis is a useful tool for creating future strategies but also has some weaknesses in practice. SWOT is the overall evaluation of a company's strengths, weaknesses, opportunities, and threats. Even it has some deficiencies, The SWOT analysis is no doubt a valuable tool in the field of business strategy because it invites decision-makers to consider important aspects of their organization's environment and helps them organize their thoughts (Wang, 2007).

Today, the Analytic Hierarchy Process (AHP) of Saaty (1980) is one of the most popular and powerful methods for decision making. AHP is generally used to derive priorities based on sets of pairwise comparisons (Forman and Peniwati, 1998). The AHP approach is a multi-criteria decision-making method that uses hierarchic or network structures to represent a decision problem and then develops priorities for the alternatives based on the decision maker's judgments throughout the system. It addresses the issues of how to structure a complex decision problem, identify its criteria (tangible or intangible), measure the interaction among them and finally synthesize all the information to arrive at priorities, which depict preferences (Dyer, 1990; Saaty, 1986, 1987, 1990).

For this purpose, first of all: the strengths and weaknesses of the forest products industry and their opportunities and threats originating from the sector and district were determined using the SWOT matrix. Afterwards the information obtained from the SWOT matrix were integrated into the AHP hierarchy and the optimum strategy was tried to find out. The used data were gotten from the industry database of Union of Chambers and Commodity Exchanges of Turkey (TOBB).
\end{abstract}

Keywords: Taşköprü, SWOT Analysis, AHP, Forest Products, Kastamonu

\section{Bir Vaka Çalişmasi: Taşköprü Orman Ürünleri Sektörünün Güncel Durumunun SWOT Analizi ve Analitik Hiyerarşi Süreci ile Değerlendirilmesi}

Bu çalışmanın amacı, Taşköprü orman ürünleri sektörünün güncel durumunun değerlendirilmesi ve optimum rekabet stratejisini belirleyerek bölgede daha etkili bir hale gelmesini sağlamaktır. Endüstrinin Taşköprü'deki durumu, SWOT analizi ve analitik hiyerarşi sürecinin (AHP) kullanıldı̆̆ı hibrit bir metotla ortaya konmaya çalışılmıştır.

SWOT analizi geleceğe dönük stratejilerin oluşturulması noktasında önemli bir araçtır fakat uygulamada bazı eksiklikleri de mevcuttur. SWOT bir şirketin tüm güçlü ve zayıf yönlerini, firsatlarını ve tehditlerini değerlendiren bir analizdir. Çeşitli eksiklikleri olmasına karşın SWOT analizinin işletme yönetimi alanında önemli bir araç olduğu su götürmez bir gerçektir Çünkü karar vericilere organizasyonlarındaki önemli noktaları göz önüne almaları noktasında ve düşüncelerini organize etmelerinde yardımcı olur (Wang, 2007)

Saaty’nin 1980 yılında ortaya koyduğu Analitik Hiyerarşi Süreci (AHP) karar verme sürecinde en çok kullanılan, güçlü metotlardan birisidir. AHP yaklaşımı çok kriterli karar verme metodu olup, hiyerarşik ya da ağ yapılarını bir karar verme problemini çözümlemek için kullanır. Sonra, karar vericinin tercihleri doğrultusunda sistem içerisindeki alternatifler için öncelikler geliştirir. Karmaşık bir sorunun yapısını ortaya koyar, kriterleri belirtir (somut veya soyut), birbirleri arasındaki etkileşim ölçer ve son olarak öncelikler doğrultusuna bütün verileri sentezler (Dyer, 1990; Saaty, 1986, 1987, 1990).

$\mathrm{Bu}$ doğrultuda öncelikli olarak, orman ürünleri sektöründen ve bölgenin bulunduğu konumdan kaynaklanan: güçlü ve zayıf yönler ile firsatlar ve tehditler SWOT analizi ile ortaya konmuştur. Sonrasında 
SWOT analizinden elde edilen bilgiler AHP yapısına uygun hale getirilerek entegre edilmiştir ve mevcut durumu daha iyi noktaya getirebilecek en iyi strateji tespit edilmeye çalışılmıştır. Araştırma kapsamında kullanılan bir takım veriler Türkiye Odalar ve Borsalar Birliği (TOBB) sanayi veri tabanından alınmıştır.

Anahtar Kelimeler: Taşköprü, SWOT Analizi, AHP, Orman Ürünleri, Kastamonu

\section{Introduction}

Taşköprü is one of the districts of Kastamonu with its own natural beauties and specialities. If it is compared to the other districts in the region it will be shown that the town is not as developed as the others in terms of forest products industry even though it has the potential. According to the TOBB (The Union of Chambers and Commodity Exchanges of Turkey): In Kastamonu, there are 96 wood related firms are active in 2016 (TOBB, 2016). The scopes of these firms vary from: door to wood based panels, timber to furniture and etc. According to the TOBB, the total amount of firms in Kastamonu is 224 and the wood based firms take approximately $43 \%$ of the province's industry. About Taşköprü: the town holds 4,4\% of the Kastamonu's total industry with 10 firms and only 3 wood related facilities (TOBB, 2016). One of these facilities in Taşköprü is a wood veneered panel facility which produces plywood and the other one is paper based and focused on cigarette paper production while the last one focused on garden furniture production. If the current situation of the other districts was investigated, it was shown that for example: in Tosya there are 3 wood veneered panel production facilities.

For increasing the contribution of the town to the economy, fulfilling the gaps in its potential was aimed in this study. Thus SWOT analysis was done to see the facts and afterwards with the help of the AHP calculations; finding out the most important factors and the best strategy was aimed. The used criteria for the AHP method's hierarchy were obtained from the SWOT analysis. For the SWOT analysis; the literature was investigated and the reports of the done studies by the governmental institutes such as: KUZKA (The North Anatolian Development Agency) about the Kastamonu, was searched deeply and with the brainstorm; it was finalised.

\section{Materials \& Methods}

The Strengths-Weakness-OpportunitiesThreats (SWOT) analysis is often used for analysing internal and external factors, evaluating the liable alternative strategies, and then for determining the best for an organization in achieving its goals and objectives. Nonetheless, the SWOT analysis as a qualitative tool which cannot numerically evaluate the effect of each factor on the strategies (Al-Refaie et al., 2016). Strengths and Weaknesses are internal (controllable) factors which support and block organisations to succeed their mission separately. Whereas Opportunities and Threats are the external (uncontrollable) factors which enable and disable organisations from accomplishing their goal (Dyson, 2004). By identifying the factors in these four fields, the organisation can recognise its fundamental capability for decisionmaking, planning and building new strategies (Phadermrod et al., 2016). The main advantage of the SWOT analysis is its simplicity. Therefore, it has various applications in many fields.

Despite its advantages it also has some important disadvantages as well. In the traditional SWOT analysis, it produces superficial and inaccurate various factors which relies on the subjective perception of an organisation staff who helped for the SWOT analysis by attending a brainstorming session where the importance of each SWOT factor was neglected in terms of prioritisation (Phadermrod et al., 2016).

Because of the disadvantage in prioritisation of SWOT factors, some researchers proposed a new variation of the SWOT analysis approach and integrated the traditional technique with some other quantitative methods such as AHP. If the literature was investigated, it can easily be proven that there are various studies using this hybrid method.

The Analytic Hierarchy Process (AHP) is a mathematical method to analyse complicated decision problems with multi-criteria. It was originally created by Saaty in 1970s. Fundamentally, AHP is a general theory of measurement based on some mathematical and psychological elements. AHP can deal with qualitative attributes as well as quantitative ones (Kurttila et al., 2000). AHP is a theory of calculations: done by using the pairwise comparisons and relies on the judgments made by the experts for deriving the priorities. With the help of this method, intangibles can be measured. 
The comparisons are made using a pre-calculated scale of absolute judgments which represents, how much more; one element dominates another with respect to a given attribute. The judgments may be inconsistent but it is possible to measure inconsistency and reduce the amount by making the judgments again. The derived priority scales (weights) are synthesised by multiplying them by the priority of their parent nodes and adding for all such nodes (Şeker and Özgürler, 2012).

Due to being a research paper, the techniques of the both methodologies were not mentioned at here in depth. Only the theoretical background was spoken for giving the basics. As it was already told in the introduction section, first of all: the SWOT analysis was done for the forest products industry in Taşköprü and then, all of the SWOT factors were turned into a hierarchy to analyse the priorities with the AHP thus the most important criterion in each group can be found out and the best strategy for fulfilling the gap in the industry may be created according to the founded criteria. For the AHP, a questionnaire was created and the judgements were made by the experts in Kastamonu University Faculty of Forestry.

\section{Results}

According to the SWOT analysis the strengths were determined like these: "logistics and geography, presence of the university, being a brand city, wood manufacturing culture at the region and being close to the raw material "while the weaknesses were determined like these: "the lack of the Entrepreneurship, lack of skilled manpower, inadequate use of the potential of forest products, non-existence of clustering at the city, the lack of the knowledge on governmental support, the lack of collaborations with external experts and the difficulty of being an industrial establishment". Also the opportunities were determined like these: "EU funds and grants, product need of the market, government grants and incentives and low-cost labour" while the threats were determined like these: "economic Instability, increasing migration, increased costs and competition with the other firms at the same region."

Due to the results of the SWOT analysis, the framework of the hierarchy was simply created like this:

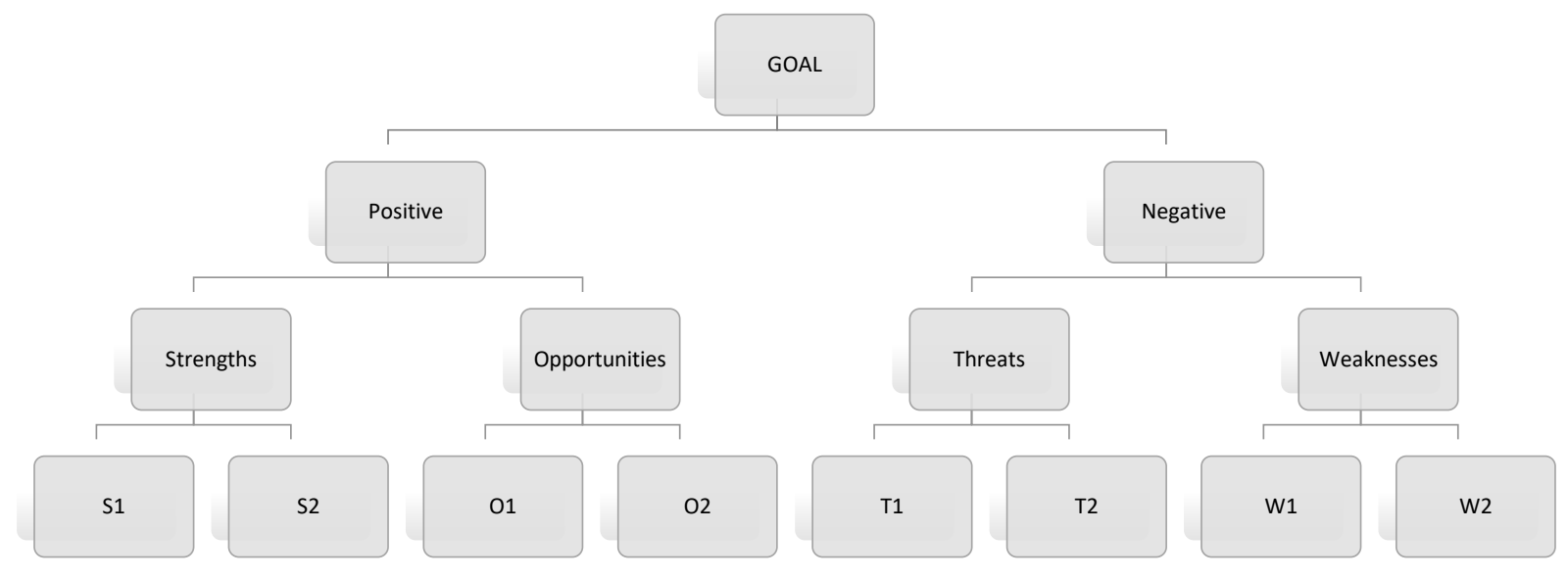

Figure 1. Hierarchic structure of the SWOT analysis for AHP

The gotten data from the responses of the experts were aggregated with geometric mean method for the AHP. The reason behind the choice of geometric mean is the calculations and explanations of the developer of AHP; Prof
Saaty. According to the calculations of the AHP, the synthesis of the problem was found like this:

The judgements were consistent they are all < then $10 \%$ inconsistency which is the suggested limit for the pairwise comparisons. 
Table 1. Overall synthesised priorities

\begin{tabular}{cccc}
\hline Name & Ideals & Normals & Raw \\
\hline EU funds and grants & 0.374518 & $\mathbf{0 . 0 5 5 3 8 3}$ & 0.018461 \\
wood manufacturing culture at the region & 0.231271 & $\mathbf{0 . 0 3 4 2}$ & 0.0114 \\
competition with the other firms at the same region & 0.107565 & $\mathbf{0 . 0 1 5 9 0 6}$ & 0.005302 \\
logistics and geography & 0.476376 & $\mathbf{0 . 0 7 0 4 4 5}$ & 0.023482 \\
the lack of the knowledge on governmental support & 0.112474 & $\mathbf{0 . 0 1 6 6 3 2}$ & 0.005544 \\
government grants and incentives & 0.556936 & $\mathbf{0 . 0 8 2 3 5 8}$ & 0.027453 \\
increasing migration & 0.141009 & $\mathbf{0 . 0 2 0 8 5 2}$ & 0.006951 \\
the lack of collaborations with external experts & 0.188335 & $\mathbf{0 . 0 2 7 8 5}$ & 0.009283 \\
economic Instability & 1 & $\mathbf{0 . 1 4 7 8 7 7}$ & 0.049292 \\
the lack of the Entrepreneurship & 0.585202 & $\mathbf{0 . 0 8 6 5 3 8}$ & 0.028846 \\
being close to the raw material & 0.570672 & $\mathbf{0 . 0 8 4 3 8 9}$ & 0.02813 \\
lack of skilled manpower & 0.202954 & $\mathbf{0 . 0 3 0 0 1 2}$ & 0.010004 \\
being a brand city & 0.259732 & $\mathbf{0 . 0 3 8 4 0 8}$ & 0.012803 \\
non-existence of clustering at the city & 0.156227 & $\mathbf{0 . 0 2 3 1 0 2}$ & 0.007701 \\
increased costs & 0.442018 & $\mathbf{0 . 0 6 5 3 6 4}$ & 0.021788 \\
inadequate use of the potential of forest products & 0.2547 & $\mathbf{0 . 0 3 7 6 6 4}$ & 0.012555 \\
product need of the market & 0.61276 & $\mathbf{0 . 0 9 0 6 1 3}$ & 0.030204 \\
the difficulty of being an industrial establishment & 0.190699 & $\mathbf{0 . 0 2 8 2}$ & 0.0094 \\
low-cost labour & 0.146376 & $\mathbf{0 . 0 2 1 6 4 6}$ & 0.007215 \\
presence of the university & 0.15254 & $\mathbf{0 . 0 2 2 5 5 7}$ & 0.007519 \\
\hline
\end{tabular}

The table 1 demonstrates the AHP calculations for the whole model. As it is shown from the table, the most important (prior) criteria were found as the "economic instability" afterwards "product need of the market" and the "lack of the entrepreneurship comes in a row. For seeing all the factors which has significant effect on the problem it is better to look at the figure below:

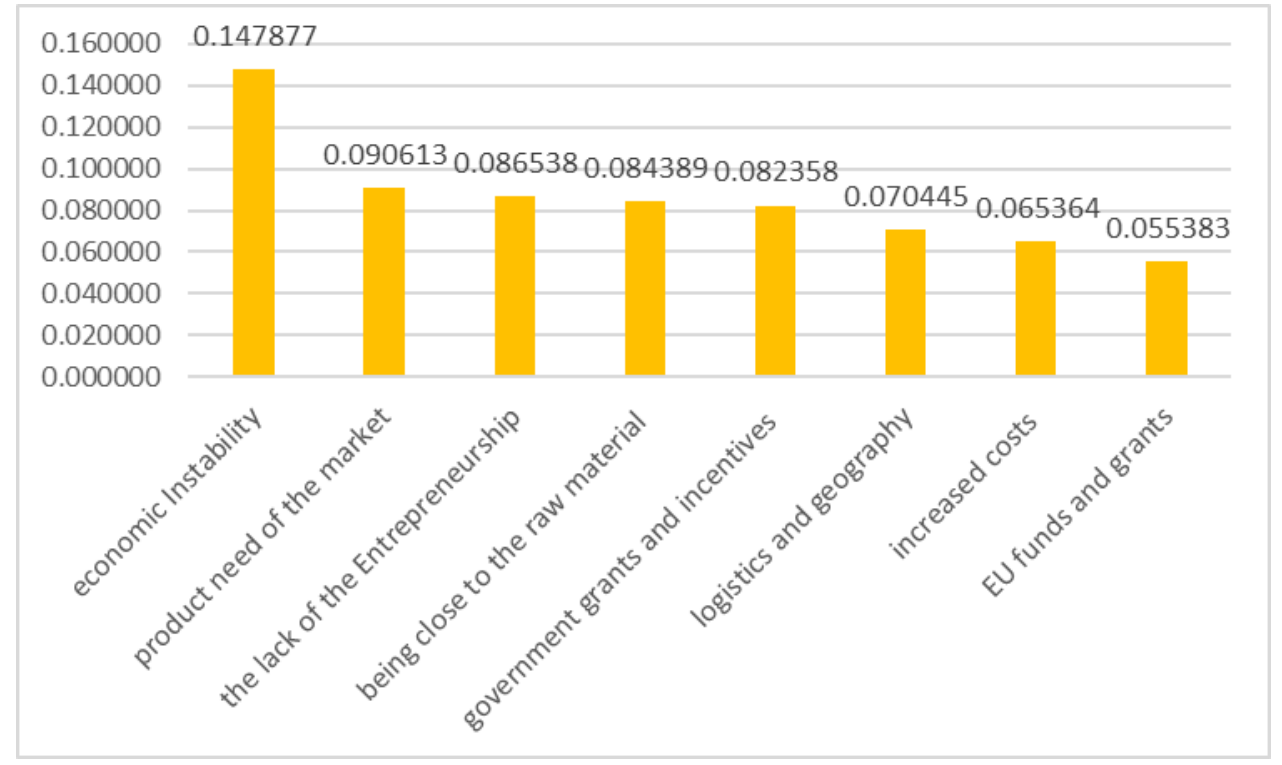

Figure 2. The most important criteria according to the AHP

According to the gotten results; for the strengths the most effective criterion was found as: "being close to the raw material", for the opportunities it was found as: "product need of 
the market." For the weaknesses the most effective one was calculated as the lack of the "entrepreneurship" and for the threats it was found as the "economic instability". In all of the judgement the most prior one was found as the "economic instability".

\section{Discussion}

Due to the done analysis it is possible to say that Taşköprü has a potential for being an important part of the Kastamonu's forest product industry. If the literature was investigated, it will be understood that it has the similarities like other districts at the region but it stays behind the others. This paper proves that it has some key points to be a home for the forestry related facilities such as: being close to the raw material and it has advantage for using the government grants and incentives because of being the part of a developing region. But also it is another fact that the investors should be encouraged to be an entrepreneur and invest in the town. The experts such as academics and etc. should attract attention and help the people who seeks such areas to invest but has not enough knowledge.

Because of being a research paper for the symposium this paper especially focused on Taşköprü and so, it has some limitations. The experts should be in large amount for participating to the judgement and the SWOT factors may vary. For the future studies this criticism should be taken into account.

\section{References}

Dyer, J. S., 1990. Remarks on the analytic hierarchy process. Management Science, 36, 249258.

Dyson, R. G., 2004. Strategic development and SWOT analysis at the University of Warwick. European Journal of Operational Research, 152, 631-640.

Forman, E., \& Peniwati, K., 1998. Aggregating individual judgments and priorities with the analytic hierarchy process. European Journal of Operational Research, 108(1), 165-169. http://doi.org/10.1016/S0377-2217(97)00244-0

Kurttila, M., Pesonen, M., Kangas, J., \& Kajanus, M., 2000. Utilizing the analytic hierarchy process (AHP) in SWOT analysis - a hybrid method and its application to a forest-certification case. Forest Policy and Economics, 1(1), 41-52. http://doi.org/10.1016/S1389-9341(99)00004-0

Phadermrod, B., Crowder, R. M., \& Wills, G. B., 2016. Importance-Performance Analysis based SWOT analysis. International Journal of Information
Management, 1-10. http://doi.org/10.1016/j.ijinfomgt.2016.03.009

Al-Refaie, A., 2016. Integration of SWOT and ANP for effective strategic planning in the cosmetic industry. Advances in Production Engineering \& Management 11(1), 49-58.

Saaty, T.L., 1980. The Analytic Hierarchy Process. McGraw-Hill Book Co., NY.

Saaty, T. L. (1986). Axiomatic foundation of the analytic hierarchy process. Management Science, 32, 841-855.

Saaty, T. L.. 1987. Concept, theory and techniques: Rank generation, preservation, and reversal in the analytic hierarchy decision process. Decision Science, 18, 157-177.

Saaty, T. L., 1990. How to make a decision: The analytic hierarchy process. European Journal of Operational Research, 48(1), 9-26.

Şeker, Ş., \& Özgürler, M., 2012. Analysis of the Turkish Consumer Electronics Firm using SWOTAHP Method. Procedia - Social and Behavioral Sciences, 58, 1544-1554. http://doi.org/10.1016/j.sbspro.2012.09.1141

The Union of Chambers and Commodity Exchanges of Turkey Industry Database. 2016. http://sanayi.tobb.org.tr/

Wang, K., 2007. A Process View of SWOT Analysis. Transformation. Proceedings of the 51st Annual Meeting of the ISSS - 2007, Tokyo, Japan. 